\title{
Kekuatan Mengikat UDHR 1948 terhadap Negara Anggota PBB. Khususnya Indonesia
}

\author{
Rukmana Amanwinata
}

\begin{abstract}
Although, the Constitution of Human Rights 1948 accepted by General Assembly of the United Nations on December 10, 1948 does not have a tightening power yurisdically, it has a more tightening power in the form of moral bound. This is due to an assumption issued by civilized nations of the United Nation members that the contain of the Article of Human Rights constitutes a minimum standard for human rights. Indonesia, which was admitted as a member of the United Nations after the Article of Human Rights 1948 issued, has morally responsible for this point. Therefore, this issue was also stated in the Temporary Constitution of the Republic of Indonesia 1950, and has been reflected on the 1945. Constitution following other regulations.
\end{abstract}

\section{Pendahuluan}

Memperhatikan perkembangan dan perjuangan hak asasi manusia pada abad 17 sampai dengan abad 19, kiranya memberikan kesimpulan bahwa hak asasi manusia yang diperjuangkan pada ketika itu hanya terbatas pada hak asasi klasik yaitu hak asasi sipil dan politik saja seperti kesamaan hak, hak atas kebebasan, hak memilih dan yang lebih menonjolkan kepentingan individu. ${ }^{\prime} \mathrm{Hal}$ ini mudah dimengerti karena hak asasi manusia yang dirumuskan pada abad 17 sampai dengan abad 19 sangat dipengaruhi gagasan hukum kodrat (natural-law) dari John Locke dan Jean Jacques Rousseau, serta di lain pihak juga sebagai resultan dari reaksi sistem konstitusional terhadap sistem pemerintahan yang absolut. ${ }^{2}$

'Miriam Budiardjo. 1989. Dasar-Dasar Ilmu Politik. Dian Rakyat. Hilm. 121.

2/bid., juga perhatikan O. Notohamidjojo. 1970. Makna Negara Hukum. Jakarta: Badan Penerbit Kristen. HIIm. 20-23. 
Berbeda pada abad 20, hak asasi klasik dianggap kurang lengkap. Oleh karena itu hak asasi manusia tidak hanya dibatasi pada hak asasi sipil dan politik, melainkan mencakup juga hak asasi di bidang ekonomi, sosial dan budaya. Hubungan ini terkenal the four freedoms (empat kebebasan yang dirumuskan Presiden Amerika Serikat, Franklin Delano Roosevelt, tahun 1941, manakala berkecamuknya Perang Dunia ll, ${ }^{\text {kh }}$ ususnya freedom keempat yaitu freedom from want (kebebasan dari kekurangan atau kemelaratan).

Mengingat isyarat dalam Mukadimah serta ketentuan Pasal 55 dan 56 The United Nations Charter, ${ }^{4}$ Perserikatan Bangsa Bangsa (PBB) yang dibentuk pada tahun 1945 telah membentuk Commission on Human Rights pada tahun 1946. Komisi bertugas untuk mempersiapkan rancangan (bill) internasional tentang hak asasi manusia yang terdiri dari tiga bagian, ialah 1) pernyataan hak asasi manusia, 2) perjanjian mengenai hak asasi manusia, dan 3) cara-cara pelaksanaannya. ${ }^{5}$

Bagian pertama memuat asas-asas umum hak asasi manusia, sedangkan bagian kedua memuat rumusan serta batas-batas pelaksanaan hak asasi manusia, dan bagian ketiga memuat tentang cara-cara pelaksanaannya yang mencakup cara-cara internasional untuk menjamin ditaatinya atau dihormatinya hak asasi manusia itu. Pada tahun 1948, Komisi berhasil menyelesaikan tugas bagian pertama yaitu merumuskan pengaturan (bill) internasional yang dituangkan dalam Universal Declaration of Human Rights (UDHR).

Deklarasi ini memuat tiga puluh pasal yang dapat dikelompokkan ke dalam tiga bagian. Bagian pertama menyangkut hak asasi sipil dan politik, bagian kedua menyangkut hak asasi atas martabat dan integritas manusia, dan bagian ketiga menyangkut hak asasi ekonomi, sosial dan budaya. ${ }^{6}$ Lain dari itu, telah diketahui pula bahwa Deklarasi tersebut pada dasarnya telah diterima secara aklamasi oleh Majelis Umum PBB (General Assembly). meskipun masih terdapat beberapa negara anggota PBB yang tidak memberikan suaranya, antara lain Uni Soviet. ${ }^{7}$

3Marbangun Hardjowirogo. 1981. Hak-hak Manusia dalam Mekanisme-mekanisme Perintis, Nasional, Regional dan Internasional. Yayasan Idayu. Hlm. 56. Lihatjuga Miriam Budiarjo. Op.Cit. Hlm. 121.

'Lihat 1982. Piagam PBB dan Statuta Mahkamah Internasional. Bandung: Binacipta. LihatjugaAmos J. Peaslee. Constitutions Nations. Martinus Nijhoff. 1970. The Hague. Serta lan Brownlie. 1971. Basic Documents on Human Rights. Oxford: Clarendon Press.

${ }^{5}$ Perhatikan Pernyataan Umum Hak-hak Manusia Suatu Ukuran Kemajuan. New York: Penerbitan Istimewa Ulang Tahun Ke-15. PBB. 10 Desember 1963.

${ }^{8} /$ bid. Perhatikan pula Paul S. Baut dan Beny Harman K. 1988. Kompilasi Deklarasi HakAsasi Manusia. Jakarta: Yayasan LBHI. HIm.9.

${ }^{7}$ Miriam Budiardjo. Op.Cit., hlm. 122. Bandingkan pula dengan lan Brownlie. Op.Cit. Hlm. 93-191. Marbangun Hardjowirogo. Op.Cit., Him. 3. Maurice Cranston. 1962. Human Rights Today. Bombay: Manaktana and Sons.HIm. 38. juga Boer Mauna. "Perkembangan Hak-hak Asasi Manusia." Dalam Jurnal Luar Negeri No. 7 Agustus 1987. Him. 81. 
- Sangat logis apabila Deklarasi tersebut mengikat negara-negara anggota PBB yang mengikuti proses perumusan Deklarasi itu. Namun, mengingat bertambah banyaknya négara anggota PBB, khususnya Indonesia yáng memasuki badan dunia itu pada tanggal 29 September 1950 dan merupakan anggota ke-60 timbul permasalahan bagaimanakah kekuatan mengikat UDHR 1948 tersebut bagi negara-negara anggota PBB yang tidak secara langsung mengikuti proses perumusannya, khususnya bagi Indonesia.

\section{Kekuatan Mengikat Deklarasi}

Berbicara tentang Deklarasi (Declaration) tidak terlepas dengan Perjanjian Internasional, sebab Deklarasi (Declaration) merupakan salah satu predikat yang diberikan kepada Perjanjian Internasioal, sebagaimana dikonstatasi Mochtar Kusumaatmadja: ${ }^{8}$

"Perianjian Internasional itu adakalanya dinamakan traktat (treaty), pakta (pact), konvensi (convention), piagam (statute), charter, deklarasi, protokol, arrangement, accord, modus vivendi, covenant, dan sebagainya". (tulisan miring dan garis bawah dari penulis).

Demikian pula J.L. Brierly ${ }^{9}$ menyatakan bahwa:
"Contractual engagements between states are called by various names - treaties, conventions, pacts, acts, declarations, protocols". (garis bawah dari penulis)

Dengan demikian, untuk menjawab pertanyaan seberapa jauh kekuatan mengikat Deklarasi dapat ditelusuri dari seberapa jauh pula kekuatan mengikat suatu Perjanjian Internasional.

Sebagaimana dimaklumi, salah satu sumber formal Hukum Internasional, seperti ditentukan dalam Pasal 38 Statuta Mahkamah internasional ialah Perjanjian Internasioal, baik yang bersifat umum maupun khusus, yang mengandung ketentuan hukum yang diakui secara tegas oleh negara-negara yang bersengketa. ${ }^{10}$ Yang dimaksud dengan Pejjanjian Intemasional adalah perjanjian yang diadakan antara anggota masyarakat bangsabangsa dan bertujuan untuk mengakibatkan akibat hukum tertentu."

D.P. O'Connel112 merumuskan:

A treaty is an agreement between states, governed by intemational law as distinct from municipal law, the form and manner of which is immaterial to the legal consequences of the act.

Suatu Perjanjian Internasional adalah suatu persetujuan antar negara, yang diatur

${ }^{8}$ Mochtar Kusumaatmadja. 1990. Pengantar Hukum Internasional. Buku l-Bagian Umum. Bandung: Binacipta. HIm. 85

9j.L. Brierly. 1972.The Law Nations. Sixth Edition. London: Oxford. Hlm. 317. Juga lihat J.G. Starke. 1977. Introduction to Intemational Law. Eighth Edition. London: Butter worth World Student Reprint. HIm. 462.

'oLihat. Piagam Perserikatan Bangsa-Bangsa dan Statuta Mahkamah Internasional. Bandung: Binacipta. 1982.

${ }^{11}$ Mochtar Kusumaatmadja. Op.Cit. Hilm. 85.

${ }^{12}$ D.P. O'Connell. 1970. Intemational Law. Second Edition. London: Volume, Stevens \& Lons. HIm. 195. 
oleh hukum internasional sebagai pembeda dengan persetujuan menurut hukum nasional, yang terhadap konsekuensi hukum pembuatan perjanjian internasional, bentuk dan caranya adalah tidak penting. Juga Oppenheim $-\mathrm{H}$. Lauterpacht dalam bukunya International Law merumuskan Perjanjian International sebagai berikut:

International treaties are conventions, or contracts, between two or more states concerning various matters of interest. ${ }^{13}$

Perjanjian Internasional adalah konvensi atau kontrak antar dua negara atau lebih mengenai berbagai macam kepentingan.

Demikian pula The Vienna Convention on The Law of Treaties 1969 yang ditetapkan pada tanggal 23 Mei $1969^{14}$ melalui ketentuan Pasal 2 ayat (1) huruf a merumuskan Perjanjian Internasional sebagai berikut:

Treaty' means as international agreement concluded between States in written form and govemed by intemational law, whether embodied in a single instrument of in two or more related instruments and whatever its particular designation.

Perjanjian adalah suatu Perjanjian Internasional ditutup di antara negara-negara di dalam bentuk tertulis dan diatur oleh hukum internasional, baik dalam satu instrumen tunggal atau dalam dua atau lebih instrumen yang berhubungan dan apapun nama instrumen tersebut.

Berdasarkan uraian di atas dapat disimpulkan bahwa:

1. Perjanjian Internasional pada hakekatnya adalah suatu persetujuan (agreement);

2. Subjek Perjanjian Internasional adalah semua subyek hukum internasional, meskipun pada kenyataannya menunjukkan bahwa sebagian besar dan yang terutama atau bahkan hampir seluruhnya yang membuat Perjanjian Internasional adalah negara dan organisasi internasional;

3. Obyek Perjanjian Internasional adalah semua kepentingan yang menyangkut kehidupan masyarakat internasional, terutama kepentingan ekonomi, sosial dan budaya;

4. Bentuk Perjanjian Internasional tidak harus dalam bentuk tertulis;

5. Hukum yang mengatur Perjanjian Internasional adalah hukum internasional, bukan nasional;

6. Predikat (sebutan) Perjanjian Internasional adalah bermacam-macam.

Suatu hal yang esensi adalah bahwa Perjanjian Internasional mengikat bagi para pihak peserta perjanjian dan harus dilaksanakan oleh mereka dengan itikad baik. ${ }^{15}$

${ }^{13}$ Oppenheim-H. Lauterpacht. 1955. International Law. Seventh Edition. Volume 1, London: Longmans \& Co. HIm. 791-792.

${ }^{14}$ Lihat Mark E. Villiger. 1985. Customary Intemational Law and Treaties. Martinus Nijhoff Publishers. HIm. 95. I.M. Sinclair. 1973. The Vienna Convention on The Law of Treaties. Monchester University Press. lan Brownlie. 1966. Principles of Public International Law. Oxford: Clarendon Press. HIm.602.

${ }^{15}$ Perhatikan Mieke Komar Kantaatmadja. "Beberapa Masalah Pokok Konvensi Wina 1969 Mengenai Hukum Perjanjian Internasional." Makalah diskusi FH UNPAD. 1974. Bandingkan pula dengan American Journal of International Law (AJIL) Vol.61 No. 1 Agustus 1967. 
Hal ini adalah sejalan dengan prinsip pacta sunt servanda sebagaimana diisyaratkan dalam Pasal 26 The Vienna Convention on The Law of Treaties 1969:

Every treaty in force is binding upon the $\because$ parties to it and must be performed by them in good faith (garis bawah dari penulis)

Untuk mengikatkan diri pada suatu Perjanjian Internasional harus dinyatakan dengan persetujuan, dan persetujuan untuk mengikatkan diri pada suatu Perjanjian Internasional itu dapat dilakukan dengan penandatanganan, ratifikasi, pernyataan turut serta (accesion) atau menerima (acceptance) suatu Perjanjian. ${ }^{16}$

Bentuk persetujuan sebagaimana diutarakan di atas atau dalam ketentuan Pasal 11 The Vienna Convention on The Law of Treaties 1969 harus dinyatakan secara tegas dalam suatu Perjanjian Internasional itu. Artinya, bahwa bentuk persetujuan suatu Perjanjian Internasional ditentukan oleh dan dalam Perjanjian Internasional yang bersangkutan (perhatikan ketentuan Pasal 12 s/d Pasal 17 The Vienna Convention on The Law of Treaties 1969). bahwa:

Dengan demikian dapat disimpulkan

1. Sesuai dengan prinsip pacta sunt servanda, Perjanjian Internasional mengikat bagi para pihak peserta Perjanjian dan harus dilaksanakan dengan iktikad baik;
2. Untuk mengikatkan diri pada suatu Perjanjian Internasional oleh para pihak peserta Perjanjian harus dinyatakan dengan persetujuan;

3. Persetujuan atas suatu Perjanjian Internasional dimanifestasikan dalam macam-macam bentuk;

4. Bentuk persetujuan atas suatu Perjanjian Internasional dinyatakan secara tegas dalam perjanjian Internasional yang bersangkutan.

Bagi pihak ketiga, suatu perjanjian Internasional tidak menciptakan baik hak maupun kewajiban tanpa persetujuan darinya, seperti dikonstatasi dalam Pasal 34. The Vienna Convention on The Law of Treaties 1969 sebagai berikut:

A treaty does not create either obligations or rights for a third State without its consent. (garis bawah penulis)

Demikian pula bahwa persetujuan dimaksud dalam Pasal 34 di atas harus diberikan secara tertulis serta kewajiban dan hak bagi pihak ketiga tersebut hendaknya dinyatakan dengan tegas dalam Perjanjian itu. Kewajiban bagi pihak ketiga tersebut adalah bahwa ia harus bertindak sesuai dengan syarat-syarat yang ditentukan oleh Perjanjian, dan ia akan tetap terikat pada Perjanjian tersebut selama ia tidak menyatakan kehendaknya yang berlainan. ${ }^{17}$ Mengenai bentuk persetujuan di atas sudah barang tentu

${ }^{16}$ Mochtar Kusumaatmadja. Op.Cit. HIm. 84 dan Pasal 11 The Vienna Convention on The Law of Treaties. 1969.

${ }^{17}$ Perhatikan Mieke Komar Kantaatmadja. Op.Cit. Hlm. 101. Llihatjuga Pasal 35, 36, dan 37 The Vienna Convention on The Law of Treaties, 1969. 
mengacu kepada ketentuan Pasal 11 The Vienna Convention on The Law of Treaties 1969.

Menurut Mieke Komar Kantaatmadja, asas yang menjadi dasar dari ketentuanketentuan di atas adalah suatu asas yang telah diterima umum dalam hukum internasional dan berasal dari hukum Romawi yakni pacta tertiis nec nocent nec prosent, suatu asas yang bertalian erat dengan prinsip kedaulatan negara dan persamaan negara. ${ }^{18}$

Kembali kepada persoalan, bagaimana kekuatan mengikat suatu Deklarasi (Declaration)? Apabila pada permulaan Bab ini dikonstatasi bahwa Deklarasi merupakan sálah satu predikat (sebutan) bagi suatu Perjanjian Internasional, maka dapat disimpulkan bahwa Deklarasi mempunyai kekuatan mengikat sebagai suatu Perjanjian Internasional. Konsekuensinya pula terhadap Deklarasi tersebut, apabila dinyatakan secara tegas, harus diberikan persetujuan sebagaimana ditetapkan dalam Pasal 11 The Vienna Convention on The Law of Treaties 1969.

Akan tetapi, pada kenyataannya terdapat Deklarasi, karena tidak dipersiapkan sebagai suatu Perjanjian, ${ }^{19}$ serta Deklarasi tersebut tidak mengisyaratkan secara tegas keharusan adanya persetujuan sebagaimana diatur dalam Pasal 11 The Vienna Convention on The Law of Treties 1969, misalnya UDHR 1948.
UDHR 1948 sebagai Standar Minimum Hak Asasi Manusia

Dirumuskannya hak asasi manusia dalam suatu dokumen internasional mengingat penghormatan terhadap hak asasi manusia itu memudar manakala terjadi perang yang melibatkan hampir seluruh dunia yaitu Perang Dunia I dan II. Kenyataan ini mendorong PBB sebagai badan dunia yang didirikan pada tahun 1945, dengan beranjak dari isyarat dalam Mukadimah serta ketentuan Pasal 55 dan 56 The United Nations Charter ${ }^{20}$ untuk membentuk Commission on Human Rights pada tahun 1946.

Sebagaimana telah diutarakan. Komisi ini bertugas mempersiapkan rancangan pengaturan (bill) internasional tentang hak asasi manusia. Sehubungan dengan itu telah disepakati pula oleh Komisi, bahwa rancangan dokumen internasional itu harus terdiri dari tiga bagian, ialah 1) pernyataan hak asasi manusia, 2) perjanjian mengenai hak asasi manusia, dan 3) cara-cara pelaksanaannya. Bagian pertama memuat asas-asas umum hak asasi manusia, sedangkan bagian kedua memuat rumusan serta batas-batas pelaksanaan hak asasi manusia, dan bagian ketiga memuat cara-cara internasional untuk menjamin ditaatinya atau dihormatinya hak asasi manusia itu.

Dalam proses penyusunannya, dalam tubuh Komisi telah timbul perbedaan

${ }^{18}$ Mieke Komar Kantaatmadja. Op.Cit. HIm. 101.

19Lihat. Pernyataan Umum Hak-Hak Manusia Suatu Ukuran Kemajuan. Op.Cit. Him. 16.

${ }^{20}$ Perhatikan Piagam Perserikatan Bangsa-Bangsa dan Statuta Mahkamah Internasional. Op.Cit. juga Amos J. Peaslee. Op.Cit. serta lan Brownlie. Op.Cit.

${ }^{21}$ Miriam Budiardjo. Op.Cit. HIm. 124. 
pendapat. Perbedaan pendapat tersebut berkenaan dengan masalah apakah dokumen internasional tersebut akan mempunyai kekuatan mengikat sebagai hukum positif yang wajib ditaati dan dilaksanakan oleh negaranegara yang mengikatkan diri, ataukah hanya berfungsi sebagai pedoman belaka. ${ }^{22}$ Setelah mengalami perdebatan serta menampung berbagai pandangan, akhirnya Komisi sepakat bahwa tugas Komisi akan diselenggarakan dalam dua tahap.

Tahap pertama ialah Komisi akan merumuskan secara singkat hak asasi. manusia dan kebebasan-kebebasan dasar sebagaimana diisyaratkan dalam Pasal 55 The United Nations Charter, dalam bentuk Deklarasi (Declaration). Dalam tahap kedua akan disusun sesuatu yang lebih mengikat daripada pernyataan belaka (something more legal binding than a more Declaration) dan bahwa dokumen itu akan berbentuk Perjanjian (Covenant). ${ }^{23}$

Hasil kerja Komisi tahap pertama ini dituangkan dalam UNIVERSAL DECLARATION OF HUMAN RIGHTS (UDHR) dan diterima baik oleh Majelis Umum (General Assembly) PBB pada tanggal 10 Desember 1948 , dengan catatan pada dasarnya negaranegara anggota PBB menerima Deklarasi itu secara aklamasi, meskipun terdapat beberapa anggota yang tidak memberikan suaranya, antara lain Uni Soviet. ${ }^{24}$ Deklarasi tersebut selain terdiri dari Preamble juga memuat 30 pasal, dengan rincian sebagai berikut:

1. Pasal 1 dan 2 memuat tentang Asas-asas Umum;

2. Pasal $3 \mathrm{~s} / \mathrm{d} 21$ memuat tentang Hak-hak Sipil dan Politik (Civil and Political Rights);

3. Pasal 22 s/d 27 memuat tentang Hak-Hak Ekonomi, Sosial dan Budaya (Economic, Social and Cultural Rights);

4. Pasal $28 \mathrm{~s} / \mathrm{d} 30$ memuat tentang Ketentuan Penutup.

Apabila Deklarasi tersebut diteliti, ternyata tidak terdapat secara tegas ketentuan tentang bentuk persetujuan sebagaimana diatur dalam Pasal 11 The Vienna Convention on The Law of Treaties 1969. Hal ini dapat dimengerti, mengingat bahwa Deklarasi tersebut tidak dipersiapkan dalam bentuk Perjanjian dan oleh karenanya tidak memerlukan pengesahan atau penandatanganan oleh negara manapun.

Dengan demikian dapat disimpulkan, bahwa bagi negara anggota PBB, baik negara anggota yang mengikuti proses penyusunannya maupun yang tidak mengikuti proses penyusunannya, yang akan mengikatkan diri terhadap UDHR 1948 tersebut tidak diperlukan persetujuannya sebagaimana diatur dalam Pasal 11 The Vienna Convention on The Law of Treaties 1969.

\section{2/bid.}

${ }^{23}$ Lihat Miriam Budiardjo. Op.Cit. HIm. 122. Bandingkan juga dengan Boer Mauna. Op.Cit. HIm. 83. Perhatikan juga Sir Francis Fallat. Human Rights. London: Europa Publications. HIm. 125. Serta Francesco Capotorti terpetik lewat R.St.J.Macdonald \& Douglas M. Johnston. 1986. The Structure and Process of International Law: Essays in Legal Philosophy Doctrine and Theory. Martinus Nijhof Publishers. Hlm. 982.

${ }^{24}$ Lihat Miriam Budiardjo. Op.Cit. HIm. 122. Bandingkan juga dengan Boer Mauna. Op.Cit. HIm. 83. Perhatikan juga Sis Francis Fallat.Op.Cit. Hlm. 125. Serta Francesco Capotorti terpetik lewatR. St. J. Macdonald \& Douglas M. Johnston. 1986. The Structure and. Op.Cit. HIm. 982. 
Meskipun demikian, karena Deklarasi tersebut telah diterima baik oleh kekuasaan tertinggi dalam masyarakat bangsa-bangsa, maka Deklarasi memiliki kekuatan mengikat yang tidak dapat diabaikan. Deklarasi ini dimaksud sebagai tujuan dan standar minimum (minimum standard) hak asasi manusia yang dicita-citakan oleh umat manusia dan pelaksanaannya dibina oleh negara-negara anggota PBB..$^{25}$ Dan apabila ini dianggap sebagai pedoman moral baik oleh pemerintah negara-negara anggota PBB maupun rakyatnya, maka Deklarasi dapat dikatakan memiliki kekuatan yang mungkin lebih tinggi daripada suatu perjanjian atau undangundang. ${ }^{26}$ Secara substansial, ketentuanketentuan yang tercantum dalam Deklarasi mengikat negara-negara anggota PBB. Hal ini terbukti dimanifikasikannya beberapa jiwa ketentuan dalam Deklarasi tersebut ke dalam hukum nasional negara-negara anggota PBB, antara lain dalam Konstitusi atau UndangUndang Dasar dan peraturan perundangundangan lainnya. Tidak ataupun negara anggota PBB yang menolaknya, bahkan pada dasarnya menerima Deklarasi itu sebagai suatu hal yang mengikat.

Berdasarkan hal itu, kiranya Deklarasi telah memenuhi kriteria sebagai suatu "kebiasaan internasional" yaitu "kebiasaan internasional, yang terbukti merupakan praktik umum yang diterima" (international custom, as evidence of a general practice accepted as law) (Pasal 38 ayat (1) huruf b Statuta Mahkamah Internasional). ${ }^{27}$

Pada sisi lain, meskipun UDHR 1948 tidak dipersiapkan dalam bentuk suatu Perjanjian, namun karena Deklarasi'mengikat dan ditaati dengan iktikad baik oleh negara-negara anggota PBB, maka hal itu adalah selaras dengan jiwa asas hukum internasional pacta sunt servanda.

Dari sisi ini dapat disimpulkan bahwa Deklarasi telah diterima dan menjadi "prinsipprinsip umum dari hukum yang diakui oleh bangsa-bangsa yang beradab" (general principles of law recognized by civilized nations) sebagaimana diatur dalam Pasal 38 ayat (1) huruf c Statuta Mahkamah Internasional.

Demikian pula, UDHR 1948 sebagai suatu norma yang diterima dan diakui oleh masyarakat internasional, maka Deklarasi juga merupakan Jus Cogens ${ }^{29}$ (peremptory norm of general international law). Pasal 53 The Vienna Convention on The Law of Treaties 1969 menyatakan bahwa:

....a a peremptory nom of general intemational law is a norm accepted and recognized by the international community of States as a

${ }^{25}$ Perhatikan Pernyataan Umum Hak-Hak Manusia Suatu Ukuran Kemajuan. Op.Cit. HIm. 16.

${ }^{26} / \mathrm{bid}$.

${ }^{27}$ Lihat GJH Van Hoof. 1983. Rethinking The Sources of International Law. Usselstein Netherlands: Proefschrift. HIm 87. Lihat juga Mochtar Kusumaatmadja. Op.Cit. Hlm. 103.

${ }^{28}$ Lihat Mieke Komar Kantaatmadja. Op.Cit. HIm.98.

29Lihat Judul Bakti. "Pengertian Jus Cogens Dalam Konvensi Wina 1969 Tentang Hukum Perjanjian." Artikel dalam Majalah Padjadjaran. Kuartal I No. 1/1981 Januari-Maret 1981. HIm. 40. Perhatikan juga Pasal 53 The Vienna Convention on The Law of Treaties 1969. 
whole as a norm from which no derogation is permutted and which can be modified only by a subsequent norm of general intemational law having the same character.

Norma dasar hukum internasional umum yaitu sebagai suatu norma yang diterima dan diakui oleh masyarakat internasional secara keseluruhan sebagai suatu norma yang tidak boleh dilanggar dan hanya dapat diubah oleh suatu norma dasar hukum internasional umum yang baru dan mempunyai sifat yang sama.

Apabila hal di atas dihubungkan dengan pendapat Verdross ${ }^{30}$ yang mengemukakan tiga ciri aturan yang dapat menjadi jus cogens hukum internasional yaitu: 1) aturan-aturan dasar yang timbul karena adanya kepentingan bersama dalam masyarakat internasional, 2) timbul untuk tujuan-tujuan kemanusiaan dan 3) harus sesuai atau selaras dengan Piagam PBB, maka jelas bahwa UDHR 1948 . memenuhi ketiga ciri di atas.

Akhirnya, sesuai dengan kesepakatan Komisi, diselenggarakanlah perumusan Komisi tahap kedua, yaitu perumusan tentang hak asasi manusia dalam suatu Perjanjian (Covenant). Dalam hubungan ini Miriam Budiardjo menyatakan bahwa perumusan hak asasi manusia dalam suatu Perjanjian (Covenant) yang memiliki kekuatan mengikat secara yuridis ternyata jauh lebih sulit dibandingkan dengan perumusan Komisi tahap pertama. ${ }^{31}$ Dari pernyataan itu jelas menunjukkan bahwa dilihat dari segi yuridis, hasil kerja Komisi tahap pertama yaitu UDHR 1948 tidak memiliki kekuatan yuridis, berbeda dengan hasil kerja Komisi tahap kedua.

Sesuai dengan materi-muatan yang terkandung dalam UDHR 1948, Komisi berhasil merumuskan dua Covenant dan satu Optional Protocol, dan diterima oleh Majelis Umum (General Assembly) PBB pada tahun 1966. ${ }^{32}$ Adapun hasil kerja Komisi tahap kedua itu adalah: 1) Intemational Covenant on Civil and Political Rights, 1966; 2) International Covenant on Economic, Sosial and Cultural Rights, 1966; 3) Optional Protocol to The International Covenant on Civil and Political Rights, 1966. Hasil kerja Komisi tahap kedua ini berbeda dengan hasil hasil kerja tahap pertama. Perbedaannya itu terletak pada bahwa untuk mengikatkan diri terhadap kedua Covenant maupun terhadap Optional Protocol harus dilakukan persetujuan sebagaimana ditetapkan dalam Pasal 11 The Vienna Convention on The Law of Treaties 1969. Hal itu secara tegas diatur dalam kedua Covenant maupun dalam Optional Protocol tersebut, yaitu Pasal 26 dan 27 The International Covenant on Civil and Political Rights 1966, Pasal 43 dan 44 The Intemational Covenant on Economic, Social and Cultural Rights 1966 dan Pasal 8 dan 9 Optional Protocol to the International Covenant on Civil and Political Rights 1966.

${ }^{30}$ Verdross. Terpetik dalam Yudha Bakti. Op.Cit. Hlm. 46.

${ }^{31}$ Miriam Budiardjo. Op.Cit. Hlm.122.

${ }^{32}$ Lihat lan Brownlie. 1971. Basic Documents on Human Rights. Oxford: Clarendon Press. Him. 199 - 237. 


\section{Pengaruh UDHR 1948 di Indonesia}

Di Indonesia, pengaruh UDHR 1948 terlihat jelas dalam KRIS 1949 dan UndangUndang Dasar Sementara (UUDS) 1950. Oleh karena itu logis apabila pada kedua Konstitusi atau Undang-Undang Dasar tersebut pengaturan tentang hak asasi manusia relatif lebih banyak dan lengkap jika dibandingkan dengan Undang-Undang Dasar 1945, karena sebagaimana dikatakan oleh Muh. Yamin:33

"Konstitusi RIS dan RI 1950 adalah satusatunya dari segala konstitusi yang telah berhasil memasukkan hak asasi seperti keputusan UNO itu ke dalam Piagam Konstitusi". (garis bawah penulis)

Yang dimaksud dengan anak kalimat yang berbunyi "....hak asasi seperti keputusan UNO ...." dalam konstatasi Muh. Yamin di atas, tidak lain adalah UDHR 1948. Dilihat dari segi perumusannyapun dapat dimaklumi, bahwa UUD 1945 dirumuskan selain diwarnai dua pandangan yang berbeda juga sebelum UDHR 1948 itu diproklamasikan, sedangkan KRIS 1949 dan lebih-lebih UUDS 1950 dirumuskan setelah diproklamasikannya UDHR 1948 tersebut.

Seperti telah dikatakan, bahwa pencantuman pengaturan tentang hak asasi manusia dalam kedua konstitusi atau undangundang dasar itu relatif lebih lengkap dan lebih banyak. Setidak-tidaknya KRIS 1949 memuat
27 pasal yaitu Pasal $7 \mathrm{~s} / \mathrm{d}$ Pasal 33, dan UUDS 1950 memuat 28 pasal yaitu Pasal $7 \mathrm{~s} / \mathrm{d}$ Pasal 34. Apabila ditelaah, ternyata bahwa pada dasarnya pasal-pasal tersebut senafas dengan ketentuan yang tercantum dalam UDHR 1948.

Hal ini menunjukkan bahwa Indonesia, meskipun pada ketika itu belum menjadi anggota PBB, yaitu pada tahun 1949, namun pencantuman ketentuan tentang hak asasi manusia dalam kedua konstitusi atau undangundang dasar tersebut telah menggunakan UDHR 1948 sebagai pedoman.

Kenyataan ini juga menjadi bukti, bahwa UDHR 1948 sebagai standar minimum pengaturan hak asasi manusia memiliki kekuatan moral, dan para penyusun KRIS 1949 serta UUDS 1950 juga merasa terikat secara moral pula. Semangat sebagaimana dilukiskan di atas juga tercermin pada awal masa Orde Baru, yaitu manakala timbul gagasan untuk penyusunan suatu perangkat hukum yang memuat pengaturan tentang HakHak Asasi Manusia dan Hak-Hak Serta Kewajiban Warga Negara dalam suatu PIAGAM yang ditetapkan dalam suatu Ketetapan Majelis Permusyawaratan Rakyat (MPR). ${ }^{34}$

Gagasan itu dijelmakan dalam Sidang Umum MPRS IV tahun 1966 berdasarkan TAP MPRS No. XIVIMPRS/1966 yang memerintahkan antara lain untuk penyusunan suatu perangkat hukum mengenai hak asasi manusia tersebut. Berdasarkan TAP MPRS itu

${ }^{33}$ Muh. Yamin. 1951. Proklamasi dan Konstitusi Republik Indonesia. Jakarta: Jambatan. HIm.92.

${ }^{34}$ Moh. Kusnardi \& Harmaily lbrahim. 1976. Pengantar Hukum Tata Negara Indonesia. Pusat Studi HTN FH-UT. HIm. 160. Bandingkan juga dengan R. Salio. Masalah Penahanan dan Jaminan Hak-Hak Asasi Manusia. Nasional Fir Yahya \& Co. HIm. 89-100. juga Sri Soemantri. 1985. Ketetapan MPR(S) Sebagai Salah Satu Sumber (HTN). Remadja Karya CV. HIm. 62. 
dibentuklah beberapa Panitia Ad Hoc, khususnya Panitia Ad Hoc IV yang bertugas menyusun tentang rincian hak asasi manusia. Hasil kerja Panitia Ad Hoc IV ini diterima oleh Majelis berdasarkan Keputusan Pimpinan MPRS No. 24/B/1967 tertanggal 6 Maret 1967, sebagai bahan pokok yang akan disebarluaskan guna penyempumaan lebih lanjut.

Selanjutnya, berdasarkan TAP MPRS No. VII/MPRS/1967 tanggal 12 Maret 1967, beberapa Panitia Ad Hoc yang dibentuk berdasarkan TAP MPRS No. XIVIMPRS/1966 diubah, antara lain Panitia Ad Hoc IV menjadi PanitiaAd Hoc B. PanitiaAd Hoc B ini kemudian mengadakan penyempumaan, yang selanjutnya dituangkan dalam bentuk rancangan TAP MPRS tentang PIAGAM HAK-HAK ASASI MANUSIADANHAK-HAK SERTAKEWAJIBAN WARGANEGARA, ${ }^{35}$ yang akan diajukan pada Sidang Umum MPRS berikutnya untuk ditetapkan dalam suatu TAP MPRS.

Perjalanan akhir Rancangan PIAGAM tersebut sangat disesalkan, karena pada Sidang Umum MPRS V tahun 1968 terjadi anti klimaks. Dalam Sidang Umum MPRS V tidak dicapai kata mufakat untuk menuangkannya dalam suatu TAP MPRS. Demikian pula MPR hasil pemilihan Umum tahun 1971, dalam Sidang Umum MPR pada bulan Maret 1973. MPR tidak berkehendak untuk melanjutkan hasil kerja Panitia Ad Hoc B tersebut bahkan berdasarkan TAP MPR No. VIMPR/1973, TAP MPRS No. XIVIMPRS/1966 dinyatakan tidak berlaku dan dicabut. ${ }^{36}$
Memang sangat disesalkan, sebab apabila diteliti beberapa pasal dalam rancangan PIAGAM tersebut secara lengkap ditransfer dari pasal-pasal yang tercantum dalam UDHR 1948. Upaya untuk mempedomani UDHR 1948 ternyata berlanjut dengan dibentuknya Komisi Hak Asasi Manusia atau Komnas HAM berdasarkan KEPPRES No. 50 Tahun 1993. Isyarat tersebut dapat dibaca pada Bab Menimbang huruf $b$ yang menyatakan bahwa bangsa Indonesia sebagai bagian dari masyarakat antar-bangsa, menghormati Piagam PBB dan Deklarasi Universal Hak Asasi Manusia PBB. Kemudian, hal itu lebih dipertegas lagi di dalam tujuan Komnas HAM (Pasal 4 huruf a Keppres No. 50 Tahun 1993).

Pada era reformasi, sebagai salah satu hasil Sidang istimewa MPR ditetapkan TAP MPR No. XVI!/MPR/1998 Tentang Hak Asasi Manusia, juga hal yang senada dengan di atas dikonstatasi pada huruf c Bagian Menimbang. Demikian pula pada tahun 1999 telah diundangkan UU No 39 Tahun 1999 Tentang Hak Asasi Manusia, yang ditindaklanjuti dengan peraturan perundang-undangan pelaksanaan lainnya, yang begitu sarat dengan pencantuman hak asasi manusia senafas dengan materi-muatan UDHR 1948.

Berdasarkan uraian di atas dapat disimpulkan bahwa penghormatan negara anggota PBB khususnya Indonesia terhadap UDHR 1948 tercermin dalam konstitusi atau undang-undang dasar -serta peraturan

${ }^{35}$ Lihat Paul S. Baut \& Beny Harman K. Op.Cit. Hlm. 235.

${ }^{36}$ Sri Soemantri. 1985. Ketetapan MPR(S) Sebagai Salah Satu Sumber Hukum Tata Negara. Remadja Karya CV. HIm. 103. 
perundang-undangan pelaksananaannya. Demikian pula, penerimaan dan pemberlakuan UDHR 1948 dalam hukum nasional Indonesia tidak melalui proses persetujuan dalam arti ratifikasi ataupun aksesi sebagaimana diatur dalam Pasal 11 The Vienna Convention on The Law of Treaties 1969 yang praktiknya di indonesia diatur dalam Surat Presiden No. $2826 / \mathrm{HK} / 60$ jo Pasal 11 UUD $1945,{ }^{37}$ karena memang tidak terdapat isyarat tentang hal itu dalam UDHR 1948 itu sendiri, melainkan seperti dikatakan oleh Mochtar Kusumaatmadja: ${ }^{38}$

"Mengingat bahwa seperti telah dikatakan di atas persoalan ini tidak diatur dalam Undang-Undang Dasar 1945, satusatunya petunjuk dalam usaha menjawab pertanyaan ini harus didasarkan atas praktik kita bertalian dengan pelaksanaan kewajiban kita sebagai peserta beberapa perjanjian internasional yang telah kita adakan. Memperhatikan kenyataan tentang hal ini penulis berpendapat kita tidak menganut teori "transformasi". Kita lebih condong pada sistem negaranegara kontinental Eropa yang disebut di halaman terdahulu yakni langsung menganggap diri kita terikat dalam kewajiban melaksanakan dan menaati semua ketentuan perianjian dan konvensi yang telah disahkan tanpa perlu mengadakan lagi perundang-undangan pelaksanaan (implementing legislation)" (garis bawah penulis).

\section{Simpulan}

Setelah dilakukan penelusuran pada uraian di atas, kiranya dapat dikemukakan beberapa simpulan; pertama, UDHR 1948 tidak dipersiapkan sebagai suatu Perjanjian, oleh karenanya tidak diperlukan penandatanganan atau peratifikasian dari negara manapun manakala negara yang bersangkutan hendak mengikatkan diri terhadap UDHR 1948 tersebut. Kedua; selain tidak dipersiapkan sebagai suatu Perjanjian, dalam UDHR 1948 juga tidak dicantumkan ketentuan mengenai bentuk perjanjian yang diisyaratkan berdasarkan The Vienna Convention on The Law of Traties 1969, berbeda dengan Internasional Covenant on Civil and Political Rights 1966, Internasional Covenant on Economic, Sosial and Culturäl Rights 1966 dan Optional Protocol to be International Covenant on Civil and Political Rights 1966. Ketiga konsekuensi tidak dicantumkannya sebagai suatu Perjanjian dan tidak dicantumkannya ketentuan tentang bentuk persetujuan di atas, maka secara formal UDHR 1948 tidak memiliki kekuatan mengikat secara yuridis. Meskipun demikian, UDHR 1948 sebagai standar minimum hak asasi manusia dan memiliki kekuatan secara moral.

Keempat, Sebagai standar minimum hak asasi manusia dan memiliki kekuatan secara moral, pertama-tama UDHR 1948 secara substansial mengikat dan ditaati serta dihormati negara-negara anggota PBB dan

${ }^{37}$ Lihat Bagir Manan. "Kekuasaan Presiden dalam Masalah dan Hubungan Internasional." Artikel dalam Majalah PAD JADJARAN. Jilid XV No. 1-2-1985. HIm.92.

${ }^{38}$ Mochtar Kusumaatmadja. Op.Cit. Him. 66. 
dimanifestasikannya ke dalam hukum nasional negara-negara yang bersangkutan. Oleh karenanya, UDHR 1948 merupakan "kebiasaan internasioal, yang terbukti merupakan praktik umum yang diterima sebagai hukum" (international custom, as evidence of a general practice accepted as law). Kedua, meskipun tidak dipersiapkan sebagai suatu Perjanjian, pentaatan dan penghormatan terhadap UDHR 1948 selaras dengan asas hukum internasional pacta sunt servanda, dan oleh karenanya memenuhi kriteria sebagai "prinsip-prinsip umum dari hukum yang diakui oleh bangsa-bangsa yang beradab" (general principles of law recognized by civilized nations). Ketiga, UDHR 1948 merupakan "Jus Cogens" (peremptory norm of general international law) karena sebagai suatu norma yang diterima dan diakui oleh masyarakat internasional.

Kelima, mengingat keanggotaannya dalam badan dunia PBB sejak tahun 1950, Indonesia sebagai negara yang tidak langsung mengikuti proses perumusan UDHR 1948, juga merasa terikat terhadap UDHR 1948 tersebut. Keterikatannya tersebut tercermin daiam KRIS 1949 dan UUDS 1950 yang relatif banyak dan lengkap mengatur tentang hak asasi manusia yang senafas dengan ketentuan dalam UDHR 1948. Demikian pula meskipun UUD 1945 dirumuskan mendahului UDHR 1948, akan tetapi jiwa UDHR 1948 terefleksikan di dalam UUD 1945. Keenam, keterikatan Indonesia terhadap UDHR 1948 tidak dilakukan melalui dan bentuk persetujuan yang berupa ratifikasi sebagaimana diatur dalam Surat Presiden No. 2826/HK/60 jo Pasal 11 UUD 1945, ataupun aksesi.

Ketujuh, timbulnya gagasan untuk menyusun perangkat hukum tentang hak asasi manusia dalam bentuk PIAGAM yang dituangkan dalam suatu Ketetapan MPRS, meskipun tidak menghasilkan ketetapan yang dimaksud, memberikan isyarat bahwa baik bentuk maupun materi muatan rancangan PIAGAM diilhami oleh UDHR 1948. Kedelapan, Pembentukan Komisi Nasional HAM (Komnas HAM) berdasarkan Keppres No. 50 Tahun 1993 merupakan bukti telah diterimanya UDHR 1948 di dalam hukum nasional, demikian pula perumusan TAP MPR No. XVIII MPR/1998 tentang Hak Asasi Manusia serta diundangkannya UU No. 39 Tahun 1999 tentang Hak Asasi Manusia.

\section{Daftar Pustaka}

Bakti, Yudha. "Pengertian Jus Cogens dalam Konvensi Wina 1969 Tentang Hukum. Perjanjian." Artikel dalam Majalah Padjadjaran. Kuartal I. No. 1/1981. Januari-Maret 1981.

Baut,, Paul S. \& Beny Harman K. 1988. Kompilasi Deklarasi Hak Asasi Manusia. Jakarta: Yayasan LBHI.

Brownlie, lan. 1966. Principles of Public International Law. Oxford: Clerendon Press.

1971. Basic Documents on Human

Rights. Oxford: Clarendon Press.

Budiardjo, Miriam. 1989. Dasar-Dasar IImu Politik. Dian Rakyat.

Cranston, Maurice. 1962. Human Rights Today. Bombay: Manaktana and Son.

Hardjowirogo, Marbangun. 1981. Hak-Hak Manusia dalam MekanismeMekanisme, Perintis, Nasional, 
Regional dan Internasional. Yayasan Idayu.

Kantaatmadja, Mieke Komar. 1974. "Beberapa Masalah Pokok Konvensi Wina 1969 Mengenai Hukum Perjanjian Internasional. " Paper diskusi UNPAD.

Kusnardi, Moh. \& Harmaily Ibrahim. 1976. Pengantar Hukum Tata Negara Indonesia. Pusat Studi HTN FH-Ul.

Kusumaatmadja, Mochtar. Pengantar Hukum Internasional. Buku I-Bagian Umum. Binacipta Bandung, 1990.

Macdonald, R.St.J. \& Douglas M. Johnston. 1986.The Structure and Process of International Law: Essays in Legal Philosophy Doctrine and Theory. Martinus Nijhoff Publishers.

Manan, Bagir. "Kekuasaan Presiden dalam Masalah dan Hubungan Internasional." Artikel dalam Majalah Padjadjaran. Jilid XV. No. 1-2-1985.

Mauna, Boer. "Perkembangan Hak-Hak Asasi Manusia di PBB." Artikel dalam Jurnal Luar Negeri. No. 7 Agustus 1987. Bandung: Alumni.

Notohamidjojo, O. 1970. Makna Negara Hukum. Jakarta: Badan Penerbit Keristen.

O'connell, D.P. 1970. International Law. Second Edition. Volume One. London: Stevens \& Sons.

Oppenhiem-Lauterpacht. 1960. International Law, Peace Longmans.

Peaslee, Amos J. 1970. Constitution Nations. the Hague: Martinus Nijhoff.
Rasjid, Harun al. "Penambahan Terhadap Kertas Kerja S. Tasrif, SH tentang HakHak Asasi Warga negara Ditinjau dari Sudut UUD'45 dan Perundangundangan." Artikel dalam Majalah HUKUM dan KEADILAN. Edisi 8. tahun 1979.

Salio, R.. Masalah Penahanan dan Jaminan Hak-Hak Azasi Manusia. Jakarta: Nasional Firma Yahya \& Co.

Sinclair, I.M. 1973. The Vienna Convention on The Law of Treaty. Manchester University Press.

Soemantri, Sri. 1979. Prosedur dan Sistem Perubahan Konstitusi. Bandung: Alumni.

1985. Ketetapan MPR(S) Sebagai Salah Satu Sumber Hukum Tata Negara. Bandung: Remadja Karya CV.

Starke, J.G. 1977. An Introduction to International Law. Eight Edition. London: Butterworth World Student Reprints.

Vallat, Sir Francis. 1970. An Introduction of The Study of Human Rights. London: Europa Publications.

Van Hoof, G.J.H. 1983. Rethinking The Sources of Intemational Law. Netheriands: Proefschrift. Usselstein.

Villiger, Mark E.. 1985. Customerry International Law and Treaties. Martinus Nijhoff Publishers.

Wahjono, Padmo. 1983. Indonesia Negara Berdasarkan Atas Hukum. Ghalia Indonesia. 
Yamin, Muh. 1951. Proklamasi dan Konstitusi Republik Indonesia. Djakarta: Djambatan 1971. Naskah Persiapan UndangUndang Dasar 1945. Jilid Pertama. Jakarta: Siguntang.

American Journal of International Law (AJIL). Vol. 61 No. 1 January 1967.
Pernyataan Umum Hak-Haḱk Manusia Suatu Ukuran Kemajuan. Penerbitan Istimewa Ulang Tahun ke-15. New York: Perserikatan Bangsa Bangsa. 1963.

Piagam Perserikatan Bangsa-Bangsa dan Statuta Mahkamah Internasional. Bandung: Binacipta. 1982.

Tiga Undang-Undang Dasar Republik Indonesia. Jakarta: Sinar Grafika. 1990.

获 